\title{
STONE IN AN URBAN SPACE - ITS POTENTIAL TO PROMOTE GEOTOURISM
}

\author{
Maria GÓRSKA-ZABIELSKA* \\ Jan Kochanowski University, Institute of Geography, Chair of Geotourism and Environmental \\ Geology, Świętokrzyska St 15, 25-401 Kielce, Poland, e-mail: maria.gorska-zabielska@ujk.edu.pl \\ Ryszard ZABIELSKI \\ Polish Geological Institute National Research Institute, \\ Rakowiecka St 4, oo-975 Warszawa, Poland, e-mail: ryszard.zabielski@pgi.gov.pl
}

\begin{abstract}
Citation: Górska-Zabielska M. \& Zabielski R. (2019). STONE IN AN URBAN SPACE - ITS POTENTIAL TO PROMOTE GEOTOURISM. GeoJournal of Tourism and Geosites, 26(3), 10331045. https://doi.org/10.30892/gtg.26327-415
\end{abstract}

\begin{abstract}
The geological heritage of Pruszków, although with an easy access, remains beyond the knowledge and consciousness of its inhabitants. Besides the short description of the area's geodiversity, the article presents ten large erratic boulders and other stone elements occurring in the town. It is indicated that they have high scientific, educational, cultural-historical, and - not less important - aesthetic values. The promotion of these values can stimulate the development of urban geotourism. Geoconservation activities can contribute to the creating the image of the town, in which the principles of sustainable development are taken into account.
\end{abstract}

Key words: geological heritage, geodiversity, georesources, erratic boulders, stone objects, geotourism, Pruszków, Mazovia region

\section{INTRODUCTION}

Stone elements in towns and the role they play have already been described many times, considering various aspects. These peculiar georesources are valuable examples of geological heritage (=geosites) occurring in towns (Rubinowski \& Wójcik, 1978; Migoń, 2012; Dowling, 2013; Del Monte et al., 2013; Lollino et al., 2015; Pica et al., 2015; Zagożdżon \& Zagożdżon, 2016; Chylińska \& Kołodziejczyk, 2018; Brocx \& Semeniuk, 2019; Pereira \& Van den Eynde, 2019; da Silva, 2019). Palacio-Prieto (2015) defines urban geosites as the places representing geological or geomorphological values, formed as a result of geological processes or created by man but closely connected with geology.

According to him these can be, among others, buildings for the construction of which rocks were used. Rocks may also be geosites (Migoń, 2012), including erratic boulders (Reynard, 2008) incorporated into an architectonically developed urban space (e.g. Duraj et al., 2017; Keiter, 2017; Grimmberger, 2017; Köppe et al., 2018; Górska-

\footnotetext{
* Corresponding author
} 
Zabielska \& Zabielski, 2018). If they link geological aspect with mysterious myths, which is an example of cultural value of an erratic bolder, they attract mankind's attention in every epoch (Motta \& Motta, 2007). The various use of stone in urban space in Poland has been recently described by Zagożdżon \& Śpiewak (2011) and Zagożdżon \& Zagożdżon (2015). The latter authors pointed out two main aspects connected with this fact, i.e. geotourist and petroarchitectural aspect. The present paper falls into the geotourist trend because its purpose is to document the stone resources in Pruszków in order to expand the tourist offer in the Warsaw agglomeration. Not less important aim of the paper is to indicate new chances of sustainable development of the district and town and to create the image of the town, which should adapt some elements of abiotic nature for tourist purposes, in accordance with the principles of environmental protection.

Georesources are the objects of interest in geotourism (among others Hose, 1995; Słomka \& Kicińska-Świderska, 2004; Newsome \& Dowling, 2006, 2010; Migoń, 2012), including urban geotourism (among others Rodrigues et al., 2011; Del Monte et al., 2013; Del Lama et al., 2015; Lollino et al., 2015; Pica et al., 2015, 2016; Chylińska \& Kołodziejczyk, 2018). Geotourism is a new branch of tourism, which appeared a few years ago, and combines sightseeing with qualified tourism. Geotourism is also a branch of cognitive tourism based on the exploration of geological objects and processes, which provides aesthetic experiences. Geotourism is also an economic activity. It offers geoproducts (e.g. Reynard et al., 2015; Farsani et al., 2011, 2017; Yuliawati et al., 2019), which are the solution for the local community empowerment bringing them real financial benefits (Xun \& Ting 2003; Dowling, 2013).

\section{GEODIVERSITY OF THE STUDY AREA}

Pruszków is a district town in south-western Mazovia, which has had the town charter for 100 years. In 2018 the number of its inhabitants was approximately 60,000. The geological past, recorded in landforms and deposits, resulted in the great geodiversity (Gray, 2004; Zwoliński, 2004; Brilha, 2016) of this area. This geodiversity manifests itself mainly in the relief of the Łowicz-Błonie Plain, which is built of ground moraine, composed of till left by the Scandinavian ice-sheet during the recessional Wartanian Stage of the Odranian Glaciations (=MIS [marine isotope stage] 6; cf. Lindner \& Marks, 2012; Marks et al., 2018, 2019) (Figure 1). The brown soils, which developed on till, are used in agriculture, also within the limits of Pruszków, in the historical Production Complex of Horticulture, which was established by Piotr Ferdynand Hoser around 1898 (Municipal Records of Monuments). The vast open areas of the Łowicz-Błonie Plain, used as meadows and arable fields, are a forefield for palace and park complexes (e.g. in Pruszków, Helenówek, Pęcice) exposing their architectural and composition values (Lewin \& Korzeń, 2008). The glacitectonically squeezed Pliocene clays (Kowalczyk \& Nowicki, 2007) were exploited in a brickyard at the turn of the 19th and 20th centuries, and consequently housing construction developed (Kaleta, 2010).

This stage of town development left the so-called „quarter of millionaires” (inhabited by the prosperous inhabitants of Pruszków, among others by the members of the "Association of Polish Mechanics from America" returning from the United States, as well as by the workers of the Rail Rolling Stock Repair Workshops and the "St. Majewski and Co." Pencil Factory; Krzyczkowski, 2009; Kaleta, 2010), several street names (e.g. Ceramic Street or Brick Street), and also the so-called „ count's clay pit ponds” (belonging to Antoni Potulicki, the last owner of Pruszków; Bielawski, 2009).

Bog iron ore (e.g. Kholodov et al., 2012; Fomenko \& Sokolov, 2019) was another raw material exploited near Pruszków and Brwinów (Ruszkowski, 2019). In the period from $2^{\text {nd }}$ century $\mathrm{BC}$ to $4^{\text {th }}$ century $\mathrm{AD}$ the resources of this natural raw material 
became the basis for the development of a large centre of production and processing of iron (Woyda, 2002, 2006; Tomczak, 2007). The objects from this period, discovered during archaeological excavations, are exhibited in the recently renovated Museum of Ancient Mazovian Metallurgy (http://mshm.pl/wp/).

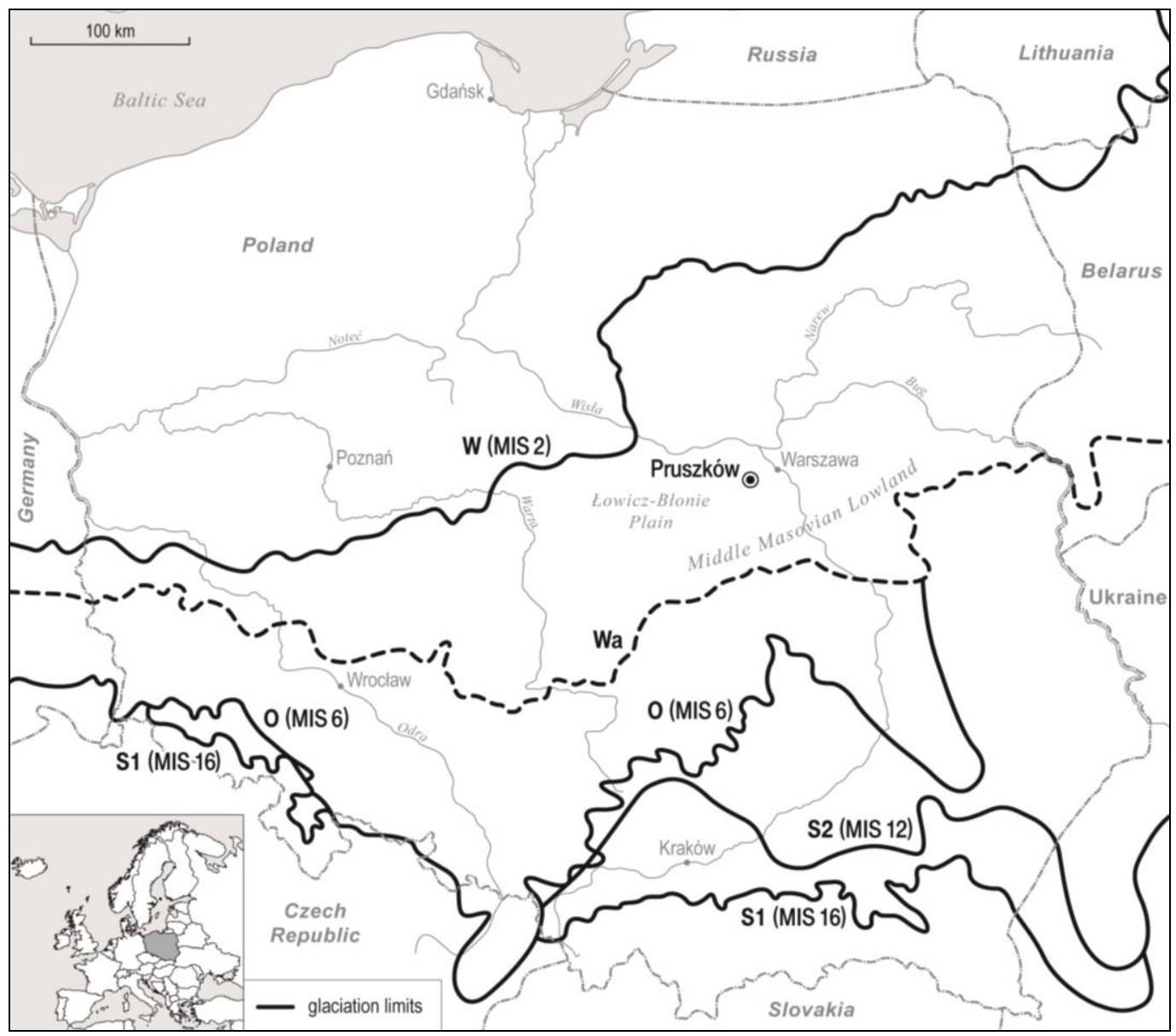

Figure 1. Location of Pruszków in relation to the extents of the Scandinavian ice-sheets according to Marks et al. (2018, 2019). S1 (MIS 16) - Saanian 1, S2 (MIS 12) - Saanian 2, O (MIS 6) - Odranian, Wa - Wartanian, W (MIS 2) - Weichselian

Water is a natural resource that should be protected but unfortunately the inhabitants of the Mazovia region rarely care about it. In the Łowicz-Błonie Plain water occurs mainly in numerous rivers and streams. The described area is drained by the Utrata River and its tributaries (Żbikówka, Regułka, Raszynka, Zimna Woda). The inhabitants of Pruszków appreciate only the recreational value of water (bathing, fishing, walking along the banks). They gladly visit the vicinity of the storage reservoir on the Utrata River in the nearby village of Komorów, the large exploitation pit (now filled with water) of the former brickyard of the Hoser brothers in the northern part of Pruszków, and the fishponds (former "count's clay pit ponds") in the Potulicki Park in the town centre (Skwara, 2002; Lewin \& Korzeń, 2008; Jakubowski, 2009). All these objects were created due to favourable natural relief and the adaptation of the Utrata River oxbows and 
old exploitation pits of the brickyard (Bielawski, 2009). The inhabitants of Pruszków use also the groundwater resources that are exploited for their needs (Kowalczyk \& Nowicki, 2007). Three water intakes exploit the Oligocene aquifer (groundwater is drawn from a depth of 238-244 m below ground surface), and one intake draws water from the Quaternary aquifer from a depth of $29.5 \mathrm{~m}$ below ground surface.

\section{METHODS}

The course of the research in the field covered an inventory of stony elements within the urban area. This procedure consists of measuring the basic dimensions of the boulders (Table 1). In turn, each boulder was considered for its Scandinavian provenance. Attention was paid to whether there is indicator erratic.

Table 1. List of the ten largest erratic boulders in Pruszków

\begin{tabular}{|c|c|c|c|c|c|c|c|}
\hline $\begin{array}{l}\text { Petrographic type, } \\
\text { provenance, age }\end{array}$ & $\begin{array}{c}\text { Length } \\
{[\mathrm{m}]}\end{array}$ & $\begin{array}{c}\text { Width } \\
\text { [m] }\end{array}$ & $\begin{array}{c}\text { Height } \\
{[\mathrm{m}]}\end{array}$ & $\begin{array}{c}\text { Diameter } \\
{[\mathrm{m}]}\end{array}$ & $\begin{array}{c}\text { Volume } \\
{\left[\mathrm{m}^{3}\right]}\end{array}$ & $\begin{array}{c}\text { Weight } \\
\text { [m] }\end{array}$ & $\begin{array}{l}\text { Location in } \\
\text { the town }\end{array}$ \\
\hline $\begin{array}{l}\text { 1. Småland granite } \\
\text { SE Sweden; } \\
\text { 1.75-1.5 bn years }\end{array}$ & 3.1 & 2.3 & 1.3 & 8.0 & 4.64 & 12.8 & $\begin{array}{l}\text { Museum of the Ancient } \\
\text { Mazovian Metallurgy } \\
52^{\circ} 09^{\prime} 52^{\prime \prime N} \\
20^{\circ} 48^{\prime} 32^{\prime \prime} \mathrm{E}\end{array}$ \\
\hline $\begin{array}{c}\text { 2. Scandinavian } \\
\text { sandstone, probably } \\
\text { of Cambrian age; } \\
541-485 \mathrm{~m} \text {. years }\end{array}$ & 2.65 & 0.55 & 1.85 & 5.85 & 1.4 & 3.9 & $\begin{array}{c}\text { John Paul II’ Square } \\
52^{\circ} 09^{\prime} 52^{\prime \prime N} \\
20^{\circ} 48^{\prime} 30^{\prime \prime E}\end{array}$ \\
\hline $\begin{array}{l}\text { 3. Rapakivi granite } \\
\text { from the Aland } \\
\text { Islands; } \\
\text { 1.7-1.54 bn years }\end{array}$ & 1.25 & 0.7 & 0.8 & 3.4 & 0.37 & 1.01 & $\begin{array}{c}\text { John Paul II' Square } \\
52^{\circ} 09^{\prime} 54^{\prime \prime N} \\
20^{\circ} 48^{\prime} 28^{\prime \prime E}\end{array}$ \\
\hline $\begin{array}{l}\text { 4. Gneiss from the } \\
\text { Baltic Shield; } \\
1.96-1.75 \text { bn years }\end{array}$ & 1.0 & 0.65 & 1.1 & 3.15 & 0.37 & 1.03 & $\begin{array}{c}\text { Centre of the town } \\
52^{\circ} 10^{\prime} 06^{\prime \prime} \mathrm{N} \\
20^{\circ} 48^{\prime} 25^{\prime \prime} \mathrm{E}\end{array}$ \\
\hline $\begin{array}{l}\text { 5. Quartzitic } \\
\text { porphyry from the } \\
\text { Åland Islands; } \\
1.7-1.54 \text { bn years }\end{array}$ & 1.4 & 1.1 & 0.9 & 3.8 & 0.72 & 1.99 & $\begin{array}{c}\text { In front of the Museum } \\
\text { DULAG } 121 \\
52^{\circ} 10^{\prime} 23^{\prime \prime N} \\
20^{\circ} 48^{\prime} 27^{\prime \prime E}\end{array}$ \\
\hline $\begin{array}{l}\text { 6. Småland granite, } \\
\text { SE Sweden; } \\
1.75-1.5 \text { bn years }\end{array}$ & 1.2 & 0.8 & 1.08 & 3.45 & 0.54 & 1.49 & $\begin{array}{c}\text { Bersohn' Square } \\
52^{\circ} 10^{\prime} 6^{\prime \prime} \mathrm{N} \\
20^{\circ} 48^{\prime} \mathrm{O} 2^{\prime E}\end{array}$ \\
\hline $\begin{array}{l}\text { 7. Gaize from the } \\
\text { bedrock of the Botnian } \\
\text { Gulf or from the } \\
\text { Lower Vistula Valley; } \\
\text { 145-66 m. years }\end{array}$ & 2.05 & 1.7 & 1.15 & 6.0 & 2.1 & 4.19 & $\begin{array}{l}\text { In front of the Social } \\
\text { Insurance Institution } \\
\text { building } \\
52^{\circ} \mathrm{O} 9^{\prime} 51^{\prime \prime} \mathrm{N} \\
20^{\circ} 47^{\prime} 38^{\prime \prime} \mathrm{E}\end{array}$ \\
\hline $\begin{array}{l}\text { 8. Granite-gneiss } \\
\text { from the Baltic } \\
\text { Shield; } \\
\text { 1.96-1.75 bn years }\end{array}$ & 1.85 & 1.95 & 0.95 & 6.0 & 1.79 & 4.93 & $\begin{array}{l}\text { In front of the Sport } \\
\text { School Complex } \\
52^{\circ} 09^{\prime} 39^{\prime \prime} \mathrm{N} \\
20^{\circ} 47^{\prime} \mathrm{O} 4 \mathrm{E}\end{array}$ \\
\hline $\begin{array}{l}\text { 9. Småland granite, } \\
\text { SE Sweden; } \\
1.75-1.5 \text { bn years }\end{array}$ & 2.15 & 1.3 & 1.0 & 5.6 & 1.46 & 4.0 & $\begin{array}{c}\text { Southern part of the town } \\
52^{\circ} 09^{\prime} 14^{\prime \prime N} \\
20^{\circ} 47^{\prime} 37^{\prime \prime} \mathrm{E}\end{array}$ \\
\hline $\begin{array}{l}\text { 10. Karlshamn } \\
\text { granite from } \\
\text { Blekinge }\end{array}$ & 2.6 & 1.7 & 1.3 & 6.45 & 3.0 & 8.26 & $\begin{array}{c}\text { Lipowa Street } \\
52^{\circ} 09^{\prime} 21^{\prime \prime N} \\
20^{\circ} 48^{\prime} 39^{\prime \prime} \mathrm{E}\end{array}$ \\
\hline
\end{tabular}

Explanation: boulder volume was calculated using the formula: $0.523 \mathrm{x}$ length $\mathrm{x}$ width $\mathrm{x}$ height (Schulz, 1964; Speetzen, 1998); boulder weight was calculated on the assumption that $1 \mathrm{~m}^{3}=2.75$ tons 
For this purpose, available atlases of such rocks as eg. Meyer (1983), Zandstra (1999), Smed \& Ehlers (2002) and Rudolph (2012, 2017) have been used. The provenance of some erratic boulders have been indicated by the boulder size (Table 1), which is mainly an effect of bedrock joint in source area (eg., Gorbatschev, 1980; Gaál \& Gorbatschev 1987; Johansson, 1988; Rodhe, 1992; Berglund et al., 1992; Lindh, 2002; Scholz \& Obst 2004). Also other specific features have been taken into consideration, like e.g. presence of crystals of blue quartz in Småland granites (Bartholomäus \& Solcher, 2002) or large round potassium feldspars surrounded by a border of sodacalcium feldspars in Åland granites (Meyer, 1983). The next stage of research has been a recognition of the role of erratic boulders in the city. The following values have been considered: cognitive, scientific, educational, culture-forming, aesthetic and geoconservation. All of them cocreate the geotourist value of stony objects within the city limits.

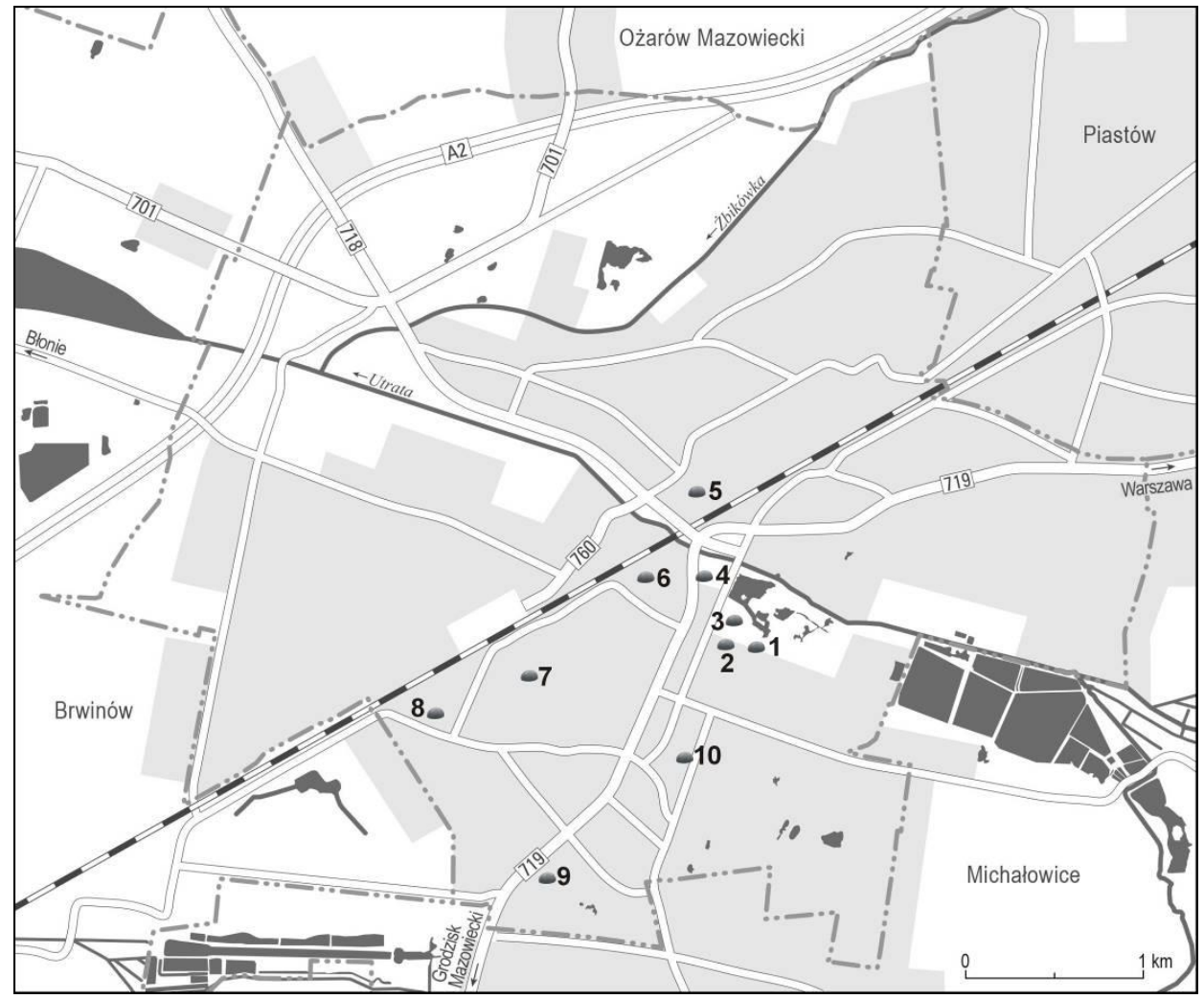

Figure 2. Location of ten largest erratic boulders in Pruszków (compare Table 1)

\section{STONY OBJECTS IN PRUSZKÓW}

Stone in Pruszków is present in natural and cultural heritage objects.

The first group includes erratic boulders, which were deposited in the Mazovia region during the recessional Wartanian Stage of the Odranian Glaciations (=MIS 6; cf. Lindner \& Marks, 2012; Marks et al., 2018, 2019). The authors of the paper know ten large erratic boulders occurring within the limits of Pruszków (Figure 2). These boulders are characterized in the Table 1 . All erratic boulders in Pruszków, although they occur ex situ, i.e. not in the places of their original glacial deposition, belong to the local geological heritage of this part of the Mazovia region, which is their cognitive and even scientific 
value. Closer observation of a boulder allows identifying its mineral composition and petrographic type, and thus the geological processes that affected it from the time of crystallization during diastrophic processes ended with orogenesis, which formed the bedrock of the present-day Scandinavia, through the transport in an ice-sheet, to the glacial deposition in the European lowlands. Based on the origin of a boulder from a particular outcrop in Scandinavia, it can be described as an indicator erratic (Korn, 1927; Lüttig, 1958; Meyer \& Lüttig, 2007). The analyses of statistically representative indicator erratics allow to indicate with high probability their source areas and to determine the directions of long-distance transport to the places where the erratics were left by an icesheet. These features create the educational value of an erratic boulder. This value is increased by some morphological features of boulder surface (formed during glacial transport) such as roundness, glacial polish and striae, crescent chatter marks (Figure $3 a, b$, No. 8 in Figure 2 and in Table 1) as well as the traces of abrasion in the form of microribs (Figure 4, No. 6 in Figure 2 and in Table 1). The latter are a record of morphogenetic processes that have continually modified the surface of a boulder since the time when it was left in dry and cold periglacial environment in the foreland of a retreating ice-sheet.
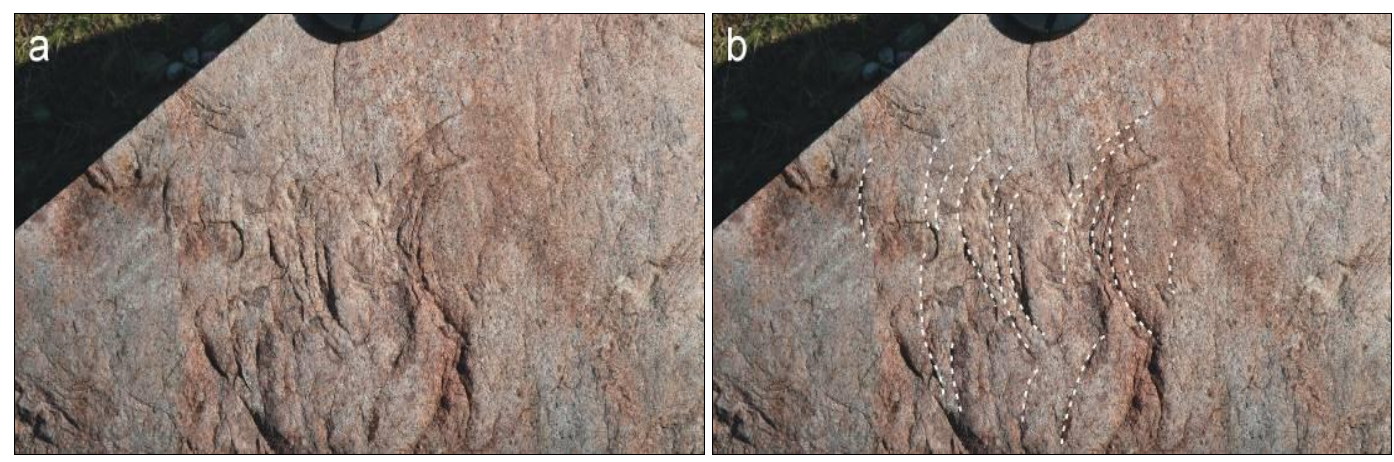

Figure 3a. Fragment of an erratic boulder - gneiss; $\mathbf{3 b}$. Visible crescent chatter marks formed by the scratching of the rock surface by the sharp edges of the crumbs carried in the ice-sheet sole.

Occurring in front of the Sport School Complex, the boulder may play an educational role

The aesthetic value of boulders is created by their size and attractive appearance. For this reason some of the boulders were set in good locations in the town or in private gardens. The boulders, objects commonly found as indestructible, resistant to the passage of time (in the scale of human life), are used as monuments or pedestals of monuments, with commemorative plaques fixed to them (Figure 5, No. 5 in Figure 2 and in Table 1; also Nos. 3, 6, 10 in Figure 2 and in Table 1). In such situations the erratic boulders play both the culture-forming and aesthetic role. The largest erratic boulder in Pruszków (No. 1 in Figure 2 and in Table 1), due to its size, is protected by law as a monument of inanimate nature (the only one of this kind in the Pruszków district). As the object of protection it has geoconservation value. Unfortunately, none of the erratic boulders in Pruszków has its own name or legend. Therefore, these boulders have no historical value and their cultural significance is small. The erratic boulders in the urban space of Pruszków are also present in the Falcon Park (Figure 6), on the lawns along the streets (e.g. ventifacts with visible abrasion microrelief, Figure 7), an also - sliced up - as the windowsills of shops (Figure 8a, b). It is worth mentioning that the number of erratic boulders in Pruszków is constantly increasing because more and more new buildings are built and their foundations reach deep into the glacial deposits so new erratic boulders are dug up. Several of the cultural heritage objects in Pruszków are connected with geology. 


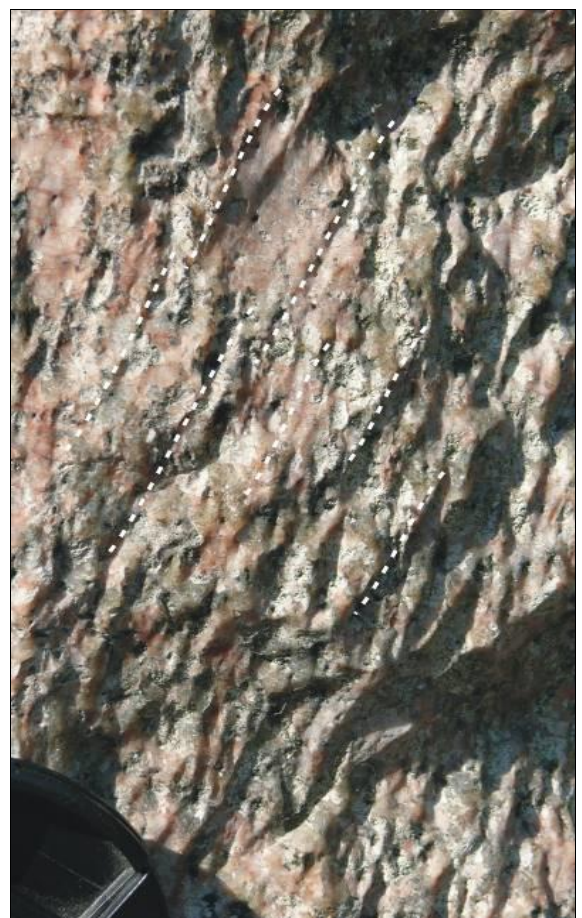

Figure 4. Fragment of an erratic boulder granite (No. 6 in Table 1). Visible parallel microribs, which are the result of abrasion destructive aeolian process affecting the boulder in dry and cold periglacial environment in the foreland of the shrinking ice-sheet

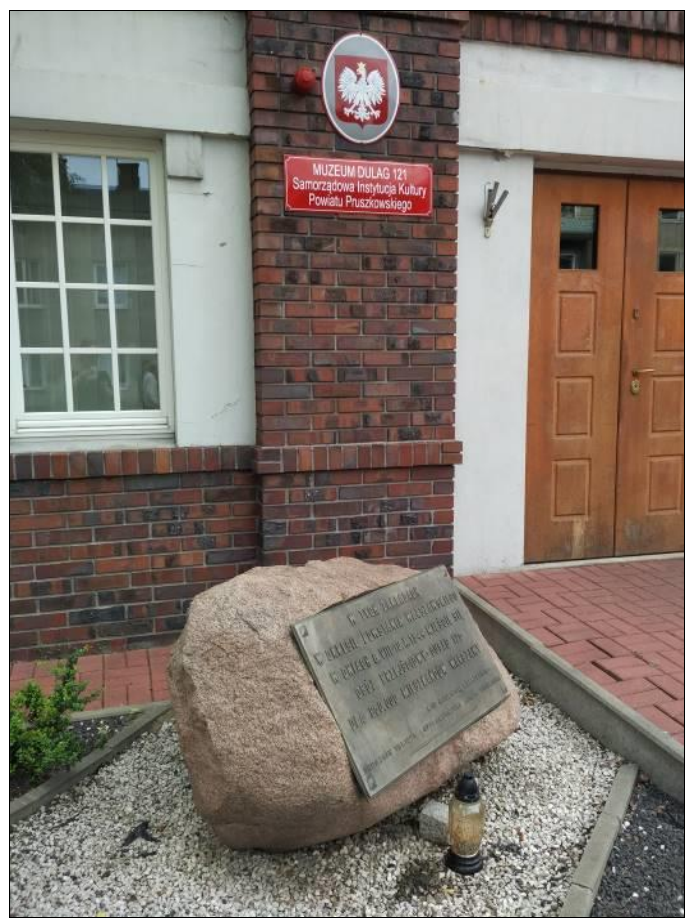

Figure 5. Commemorative plaque on an erratic boulder in front of the Museum

DULAG 121. The rock plays here the culture-forming and aesthetic role

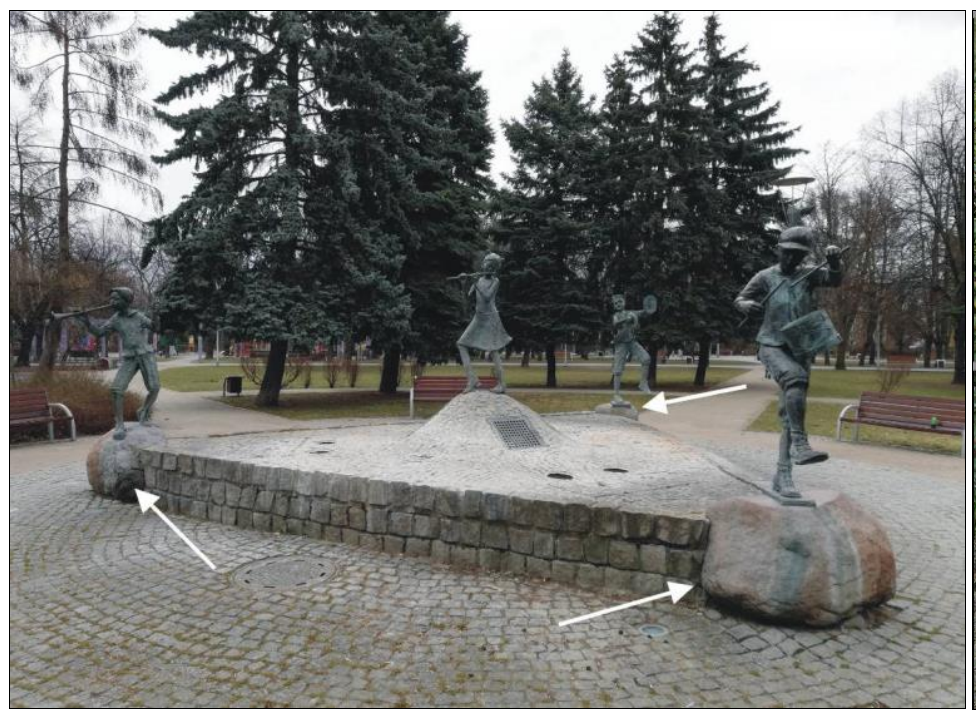

Figure 6. Three abraded erratic boulders in the Falcon Park, centre of Pruszków, play aestetic role

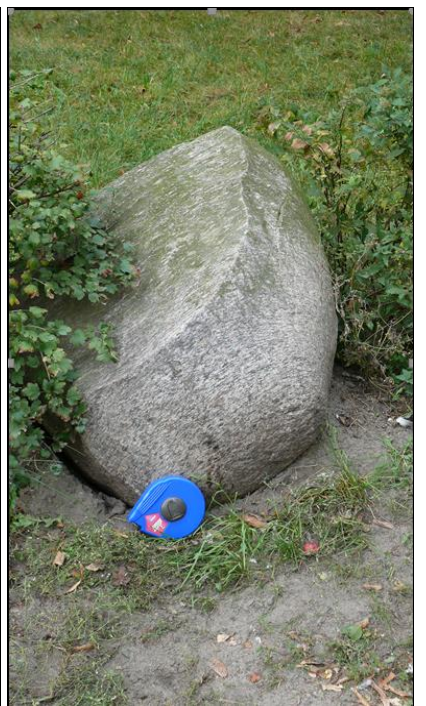

Figure 7. A model example of ventifact might have played an educational role in the town 
Stones, though not necessarily Scandinavian erratics, are also present in gabions (Italian Gabbione - cage), i.e. steel cages filled with the coarse-gravel fraction. They have, besides aesthetic and decorative, also a practical function, e.g. they stabilize slopes, for example in the Żwirowisko Park (former gravel pit, Figure 9). Gabions are also the original fences of private properties (Figure 10). Stone objects are commonly found in the Pruszków cemeteries and in the historic Jewish cemetery (Figure 11). Most of the matzhevas in the Jewish cemetery were made of the so-called Kunów sandstone (Lower Jurassic), exploited in the vicinity of Kunów near Ostrowiec Świętokrzyski (eastern part of the Świętokrzyskie Province). This sandstone has been commonly used as the material for architectural details and sculptures. That is why it is found in many cemeteries in the Mazovia region.
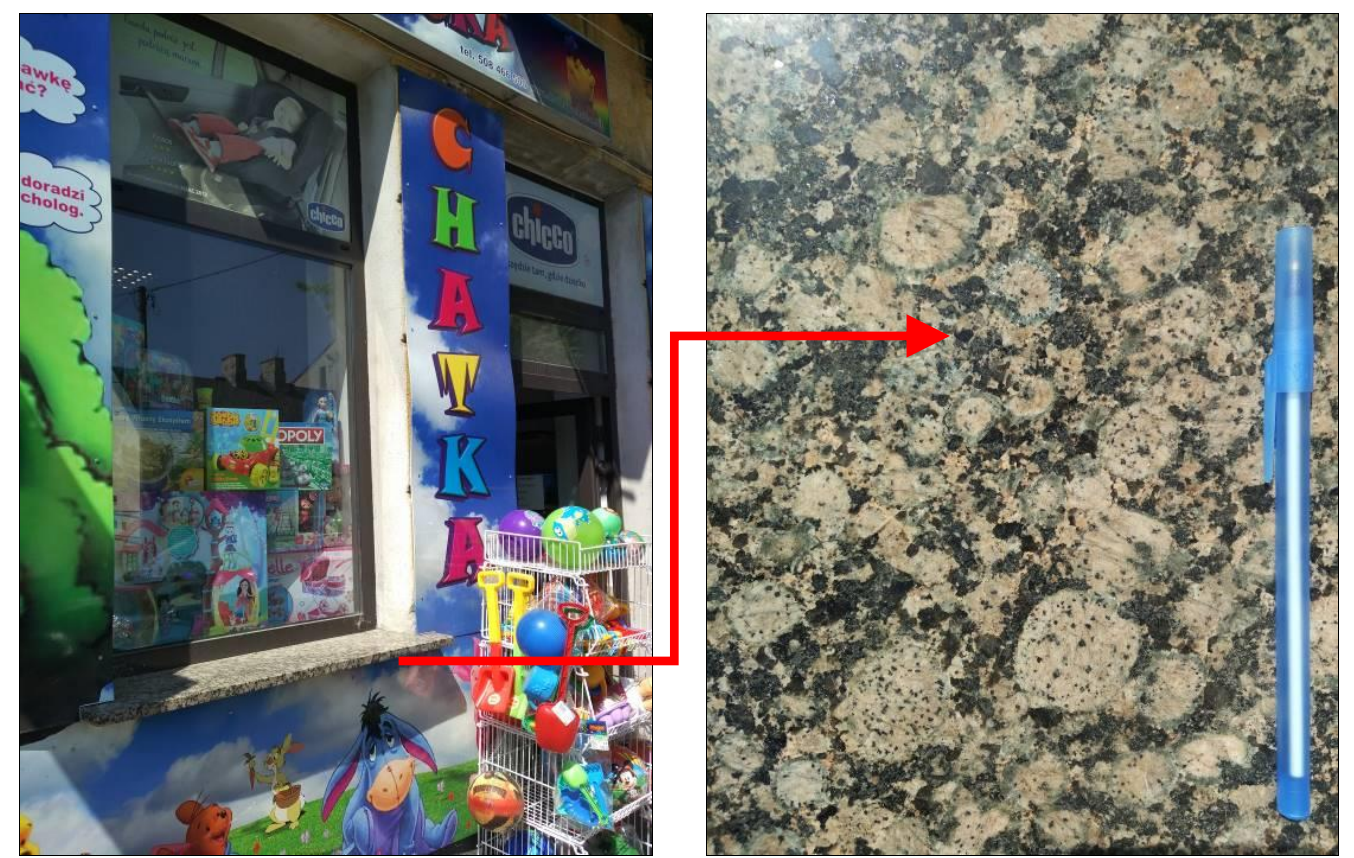

Figures 8a \& 8b. The windowsills of a toy shop were made of rapakivi granite, the outcrops of which occur on the Åland Islands

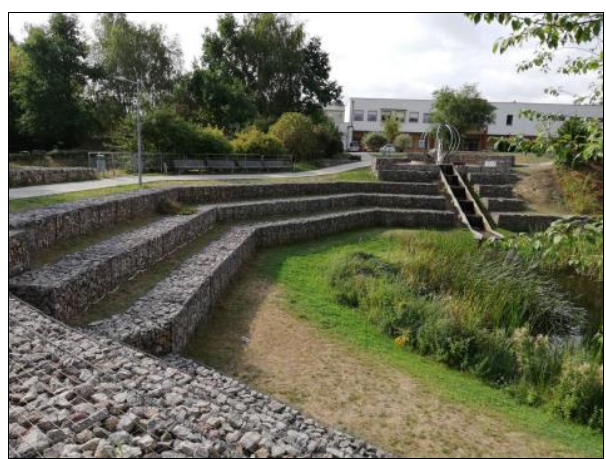

Figure 9. Gabions in the

Żwirowisko Park stabilize the slopes of the former gravel pit and have aesthetic and decorative function

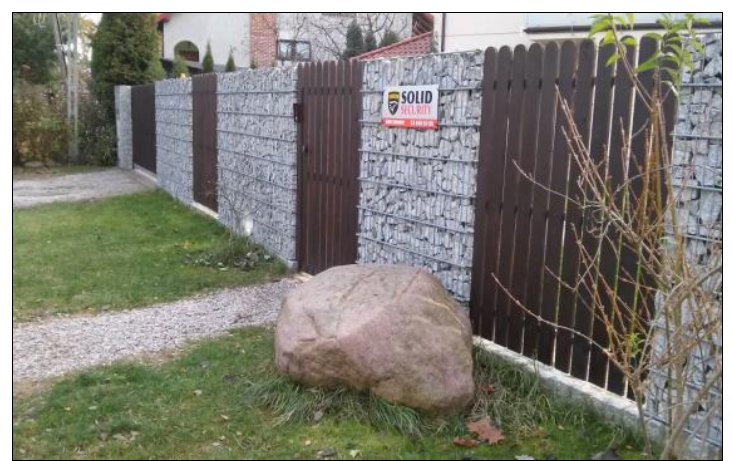

Figure 10. Gabions are the original fences of private properties in Pruszków 


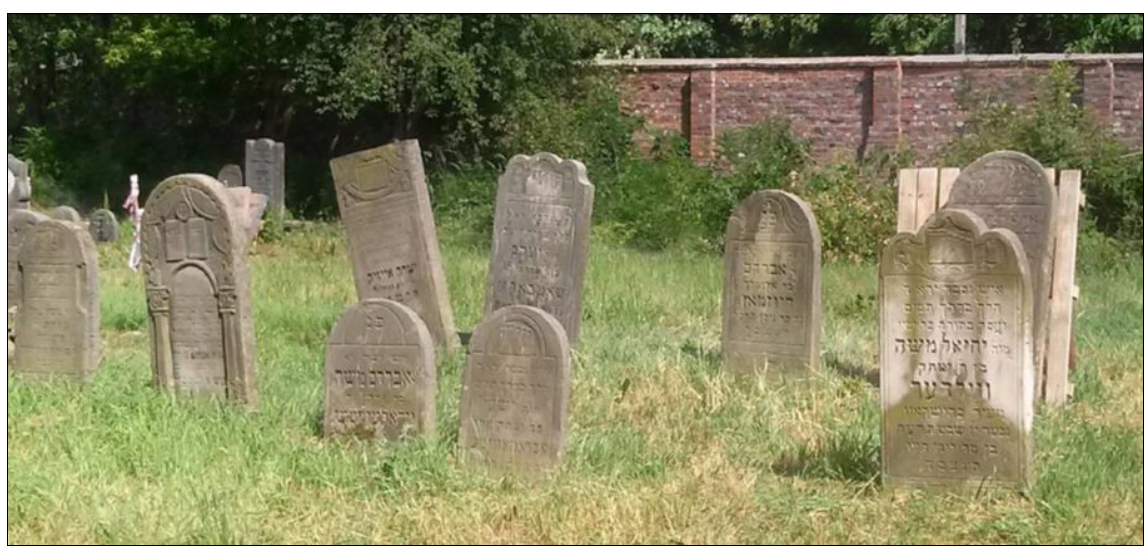

Figure 11. Stone is present in the town, among others, in the historic Jewish cemetery

The outer walls of the building of District Authority Office are covered with the Novabrik elevation brick. It is made of the mixture of natural aggregates: granite, marble and mica (Figure 12). Plasticizers, binders and colorants were added to the mixture to improve the visual and technical characteristics of brick.

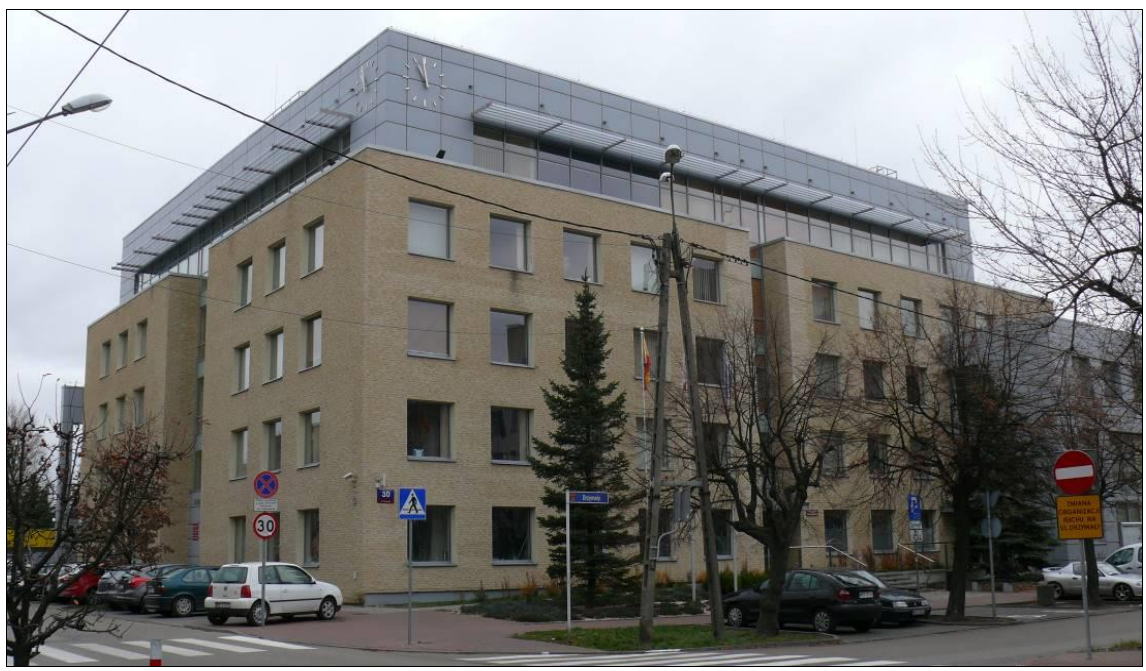

Figure 12. The outer walls of the building of District Authority Office are covered with the elevation brick made of the mixture of natural aggregates: granite, marble and mica

\section{DISCUSSION}

The stony objects of Pruszków are not present in the awareness of inhabitants. The initial survey conducted among the inhabitants of Pruszków does not arouse optimism. Though stone material has been present in the town for a long time and within reach, few people notice it, let alone exploit its educational or cognitive values. In some cases the aesthetic values of boulders were taken into account so they were set in good locations in order to commemorate an important person or event. Consequently, such boulders play a historical-cultural role. And in all, erratic boulders have potential to promote urban geotourism. Based on them, an educational or even geotourist path could be marked out taking into account the assumptions of the strategy of hands-on activities (Brzezińska- 
Wójcik, 2015), which consist in the active and emotional commitment of tourists or pupils, and thus making their education more effective. Therefore, the educational values of erratic boulders should be noticed by the Pruszków teachers who complain about difficult contact with geological exhibits (the closest collection of rocks is in the Geological Museum of the Polish Geological Institute in Warsaw).

Geotourists who will see new attractive objects on the map of Pruszków, will decide to come to the town to get to know their history. It is therefore necessary for the municipal authorities to have (even temporarily) a specialized geo-storyteller (Wolniewicz 2019) or a guide who will impart the necessary knowledge in a professional way. It depends on his/her qualifications whether the persons interested (geoturists) notice the value of the object that affects the overall assessment of the geodiversity of the region. The transfer of knowledge should be accompanied by a leaflet or folder, and preferably a chapter in the monograph/tourist guide to Pruszków or Warsaw surroundings. Publications should be printed in a local printing house and available in the Pruszków bookshops, kiosks, coffee houses, and similar institutions. It is worth adding that the authors of this paper tried to disseminate knowledge among the inhabitants of Pruszków publishing every month a geological column in a local journal and organizing educational walks through the town. Not less interesting are innovative field games, like geocaching (https://www.geocaching.com/play access on 11.06.2019) or Tourist and Recreation Orienteering Games (http://trino.pttk.pl/ in Polish access on 11.06.2019).

Tourists, staying in the town, will make use of the gastronomic offer and will be interested in buying souvenirs. It is in the interest of the municipal authorities to meet the needs of tourists by the development of the appropriate paratourist infrastructure.

The inhabitants will profit from the development of (geo) tourism because it will result in the job creation. Expanding the urban tourist offer is urgent because - according to the results of the research commissioned by the Pruszków Municipal Council (Pruszków Stop, 2007) - as much as 75\% of the surveyed inhabitants (from the group of 450 people aged 25-60) do not see the tourist values of their town.

\section{CONCLUSION}

The authors hope that the implementation of the above-mentioned ideas will increase the Pruszków inhabitants' knowledge of the geological past of the town's immediate surroundings, of the recent history of the town experiencing a building boom or, finally, of the plans of Pruszków development founded on urban geotourism.

Properly exposed objects of inanimate nature will sustain and strengthen the ties of inhabitants with their town through the environment, culture, aesthetics, and heritage (cf. National Geographic, 2005; Reynard, 2008). Their role in the sustainable development of the district and town cannot be overestimated. They contribute to creating the image of the town, in which the elements of abiotic nature are adapted for tourist purposes, in accordance with the principles of environmental protection.

Finally, it should be noted that local initiatives, increasing awareness among the inhabitants, and the promotion of all the geotourist values will certainly help to draw attention to the need for stronger protection of the inanimate resources of the Earth.

\section{Acknowledgment}

This contribution presents some results from research project No. 612502 (statutory investigations at the Jan Kochanowski University in Kielce). The authors acknowledge to anonymous reviewer for their thoughtful suggestions and comments. The authors thank M. Wilgat for English translation, M. Gościńska-Kolanko for drawing Figs 1 and 2, and share the participation in the study as follows: MGZ 70\%, RZ 30\%. M. GórskaZabielska have taken all photographs. 


\section{REFERENCES}

Bartholomäus, W. A. \& Solcher, J. (2002). The less known properties of blue quartz. Geschiebekunde Aktuell, no. 18 , vol. 3 , p. 99-106.

Berglund, J., Larson, S. A. \& Stigh, J. (1992). Features of the Protogine Zone, south central Sweden. Geologiska Föreningens i Stockholm Förhandlingar, no. 114, p. 337-339.

Bielawski, P. (2009). Pruszków. Plan Miasta [Pruszków. City plan]. Urząd Miasta w Pruszkowie.

Brilha, J. (2016). Inventory and Quantitative Assessment of Geosites and Geodiversity Sites: a Review. Geoheritage, no. 8, vol. 2, p. 119-134. https://doi.org/10.1007/s12371-014-0139-3 [access 12.06.2019].

Brocx, M. \& Semeniuk, V. (2019). Building Stones Can Be of Geoheritage Significance. Geoheritage 11: 133-149. https://doi.org/10.1007/s12371-017-0274-8.

Brzezińska-Wójcik, T. (2015). Strategia hands-on activity w kreowaniu geoproduktów w kontekście edukacji, interpretacji i promocji geodziedzictwa na Roztoczu (Środkowozachodnia Polska) [Hands-on activity strategy in creating geoproducts in the context of education, interpretation and promotion of geoheritage in Roztocze (Central-Western Poland)]. Zeszyty Naukowe Uniwersytetu Szczecińskiego 847. Ekonomiczne Problemy Turystyki, no. 1, vol. 29, p. 169-193.

Chylińska, D. \& Kołodziejczyk, K. (2018). Geotourism in an urban space? Open Geoscience, no. 10, p. 297-310.

da Silva, C., M. (2019). Urban Geodiversity and Decorative Arts: the Curious Case of the "Rudist Tiles" of Lisbon (Portugal). Geoheritage, no. 11, p.151-163 https://doi.org/10.1007/s12371-O17-0253-O

Del Lama, E., A., De La Corte Bacci, D., Martins, L., Da Gloria Motta Garcia, M. \& Kazumi Dehira, L. (2015). Urban Geotourism and the Old Centre of São Paulo City, Brazil. Geoheritage, no. 7, vol. 2, p. 147-164.

Del Monte, M., Fredi, P., Pica, A. \& Vergari, F. (2013). Geosites within Rome City center (Italy): a mixture of cultural and geomorphological heritage. Geografia Fisica e Dinamica Quaternaria, no. 36, p. 241-257.

Dowling, R., K. (2013). Global Geotourism - An Emerging Form of Sustainable Tourism. Czech Journal of Tourism, no. 2, vol. 2, p. 59-79.

Dryglas, D. \& Miśkiewicz, K. (2016). Construction on the geotourism product structure on the example from Poland. 14 $4^{\text {th }}$ International Multidisciplinary Scientific Geoconference SGEM, Geoconference on Ecology, Economics, Education and Legislation, 17-26.06.2014, Albena, Bułgaria. Conference Proceedings, vol. II, p. 155-162.

Duraj, M., Niemiec, D., Cheng, X. \& Koleňák, P. (2017). Vestiges of glacial action in Ostrava: their significance for an application in geotourism. World Multidisciplinary Earth Sciences Symposium (WMESS), IOP Conf. Series: Earth and Environmental Science, no. 95; doi: 10.1088/1755-1315/95/5/052014

Farsani, N. T., Coelho, C., Costa, C. \& Neto de Carvalho, C. (2011). Geoparks and Geotourism. New Approaches to Sustainability for the 21st Century. BrownWalker Press.

Farsani, N. T., Mortazavi, M., Bahrami, A., Kalantary, R. \& Bizhaem, F. K. (2017). Traditional crafts: A tool for geo-education in geotourism. Geoheritage, no. 9, vol. 4, p. 577-584. DOI 10.1007/s12371-016-0211-2

Fomenko, A.I. \& Sokolov, L.I. (2019). Study of Sorption Properties of Bog Ores for Extraction of Manganese and Iron Ions from Ground Water. Russian Journal of Applied Chemistry, no. 92, vol. 2, p. 288-294.

Gaál, G. \& Gorbatschev, R. (1987). An outline of the Precambrian evolution of the Baltic Shield. Precambrian Research, no. 35, p. 15-52.

Gminna Ewidencja Zabytków [Municipal Records of Monuments], Urząd Miasta Pruszkowa, http://www. pruszkow.pl/urzad/planowanie-przestrzenne/gminna-ewidencja-zabytkow [access 8.05.2017].

Gorbatschev, R. (1980). The Precambrian development of southern Sweden. Geologiska Föreningens $i$ Stockholm Förhandlingar, no. 102, p. 129-136.

Górska, M. (2006). Fennoscandian erratics in glacial deposits of the Polish Lowland - methodical aspects. Studia Quaternaria, no. 23, p. 11-15.

Górska-Zabielska, M. \& Zabielski, R. (2018). Geotourism Development in an Urban Area based on the Local Geological Heritage (Pruszków, Central Mazovia, Poland). In M.J. Thornbush \& D.A. Casey (Eds.), Urban Geomorphology. Landforms and Processes in Cities. Elsevier, Chapter 3, p. 37-54.

Gray, M. (2004). Geodiversity: Valuing and Conserving Abiotic Nature. John Wiley \& Sons Ltd ISBN 9780470848951.

Grimmberger, G. (2017). Der Davids-Stein bei Utzedel - ein „neues altes“ Geotop [The David Stone at Utzedel a "new old" geotope]. Geschiebekunde Aktuell, no. 33, vol. 3, p. 101-103.

Hose, T.A. (1995). Selling the story of Britain's stone. Environmental Interpretation, no. 10, vol. 2, p. 16-17. https://www.researchgate.net/publication/279529623_Geo-produkty_w_geoparkach_i_geoturystyce_ Geo-products_in_geoparks_and_geotourism.

Jakubowski, T. H. (2009). Lata prawie bezgrzeszne [Years almost sinless]. Powiatowa i Miejska Biblioteka Publiczna im. H. Sienkiewicza w Pruszkowie, Pruszków.

Johansson, Å. (1988). The age and geotectonic setting of the Småland-Värmland granite-porphyry belt. Geologiska Föreningens i Stockholm Förhandlingar, no. 110, p. 105-110.

Kaleta, J. (2010). Pruszków przemysłowy [Industrial Pruszków]. Wydawnictwo Powiatowa i Miejska Biblioteka Publiczna im. H. Sienkiewicza w Pruszkowie, Pruszków. 
Keiter, M. (2017). Die „Grossen Sieben” und der neue Findlingsgarten in Bielefeld - Botschafter vom saalezeitlichen Eisrand [The „Big Seven“ and the new Erratic Boulders Garden in Bielefeld - Messengers from the Saalian Ice Margin]. Geschiebekunde aktuell, no. 33, vo. 4, p. 119-129.

Kholodov, V.N., Nedumov, R.I. \& Golubovskaya, E.V. (2012). Facies Types of Sedimentary Iron Ore Deposits and Their Geochemical Features: Communication 1. Facies Groups od Sedimentary Ores, Their Lithology, and Genesis. Lithology and Mineral Resources, no. 47, vol. 6, p. 447-472.

Köppe, E.-F., Zutz, H.-D. \& Keiter, M. (2018). Herkunft und Geschichte von drei Findlingen auf dem Bielefelder Stadtgebiet [Origin and history of three boulders an the Bielefeld municipal area]. Geschiebekunde aktuell, no. 34, vol. 2, p. 65-67.

Korn, J., (1927). Die wichtigste Leitgeschiebe der nordischen kristallinen Gesteine im norddeutschen Flachlande. Preußische geologische Landesanstalt Berlin, pp. 64 (in German).

Kowalczyk, A. \& Nowicki, Z. (2007). Warszawa [Warsaw]. In Z. Nowicki (ed.), Wody podziemne miast wojewódzkich Polski. Informator Państwowej Służby Hydrogeologicznej, Warszawa, p. 221-242.

Krzyczkowski, H. (2009). Dzielnica milionerów [Millionaire's district]. Wydawnictwo Powiatowa i Miejska Biblioteka Publiczna im. H. Sienkiewicza w Pruszkowie, Pruszków.

Lewin, M. \& Korzeń, J. (2008). Park Kulturowy Gminy Michałowice jako narzędzie ochrony walorów i środowiska kulturowego gminy Michałowice [Cultural Park of the Michałowice Commune as a tool to protect the values and cultural environment of the Michałowice commune]. Wydawnictwo Gmina Michałowice.

Lindh, A. (2002). The southern part of the Transscandinavian Igneous Belt. Beiheft zum European Journal of Mineralogy, no. 14, vol. 1, p. 185-217.

Lindner, L. \& Marks, L. (2012). O podziale klimatostratygraficznym kompleksu środkowopolskiego w plejstocenie Polski [Climatostratigraphic subdivision of the Pleistocene Middle Polish Complex in Poland]. Przeglad Geologiczny, no. 6o, vol. 1, p. 1-10.

Lollino, G., Giordan, D., Marunteanu, C., Christaras, B., Yoshinori, I. \& Margottini, C. (2015). Engineering Geology for Society and Territory, Vol. 8 Preservation of Cultural Heritage. Springer.

Lüttig, G. (1958). Methodische Fragen der Geschiebeforschung. Geologisches Jahrbuch, no. 75, p. 361-418.

Marks, L., Bińka, K., Woronko, B., Majecka, A. \& Teodorski, A. (2019). Revision of the late Middle Pleistocene stratigraphy and palaeoclimate in Poland. Quaternary International, https://doi: 10.1016/j.quaint.2019.02.023.

Marks, L., Karabanov, A., Nitychoruk, J., Bahdasarau, M., Krzywicki, T., Majecka, A., Pochocka-Szwarc, K., Rychel, J., Woronko, B., Zbucki, Ł., Hradunova, A., Hrychanik, M., Mamchyk, S., Rylova, T., Nowacki, Ł. \& Pielach, M. (2018). Revised limit of the Saalian ice sheet in central Europe. Quaternary International, no. 478 , p. 59-74.

McDonnell, M. J. \& MacGregor-Fors, I. (2016). The ecological future of cities. Science Magazine, no. 352, vol. 6288, p. 936-938.

Meyer, K.-D. (1983). Indicator pebble and stone count methods. In J. Ehlers (Ed.), Glacial deposits in NorthWest Europe. Balkema, Rotterdam, p. 275-287.

Meyer, K.-D. \& Lüttig, G., (2007). What do we mean by indicator erratic? Geschiebekunde aktuell, no. 23, vol. 4, p. 106-121 (in German).

Migoń, P. (2012). Geoturystyka [Geotourism]. Wydawnictwo Naukowe PWN, Warszawa.

Miśkiewicz, K. (2015). Geoprodukty w Geoparkach i Geoturystyce [Geoproducts in geoparks and geotourism]. I Ogólnopolskie Forum pt.: „GEO-PRODUKT: od geologii do produktu turystycznego”. Kielce, 2424.09.2015. In. www.researchgate.net [online], [access 10.04.2017]

Motta, L. \& Motta, M. (2007). Erratic blocks: from protector beings to geosites to be protected. Geological Society, London, Special Publications, no. 273, vol. 1, p. 315-327. doi:10.1144/GSl.SP.2007.273.01.24

Newsome, D. \& Dowling, R. (2006). The scope and nature of geotourism. In D. Newsome \& R. Dowling (Ed.), Geotourism. Sustainability, impacts and management. Oxford, UK, Elsevier/ Heineman Publishers, p. 3-25.

Newsome, D. \& Dowling, R. (2010). Geotourism: The Tourism of Geology and Landscape. Oxford: Goodfellow Publisher.

Palacio-Prieto, J.L. (2015). Geoheritage within Cities: urban geosites in Mexico City. Geoheritage, no. 7, vol. 4, p. 365-373.

Pereira, D. \& Van den Eynde, V.C. (2019). Heritage Stones and Geoheritage. Geoheritage, no. 11, p. 1-2. https://doi.org/10.1007/s12371-019-00350-9.

Pica, A., Grangier, L., Reynard, E., Kaiser, Ch. \& Del Monte, M. (2016). GeoguideRome, urban geotourism offer powered by mobile application technology. In Abstracts EGU General Assembly 2016, 17-22 April 2016, Vienna Austria, p. 941.

Pica, A., Vergari, F., Fredi, P. \& Del Monte, M. (2015). The Aeterna Urbs Geomorphological Heritage (Rome, Italy). Geoheritage, no. 8, vol. 1, p. 1-12.

Reynard, E. (2008). Scientific research and tourist promotion of geomorphological heritage. Geografia Fisica e Dinamica Quaternaria, no. 31, p. 225-230.

Reynard, E., Kaiser, Ch., Martin, S. \& Regolini, G. (2015). An Application for Geosciences Communication by Smartphones and Tablets. In G. Lollino et al. (Ed.), Engineering Geology for Society and Territory Vol. 8 Preservation of Cultural Heritage. Springer, p. 265-272.

Rodhe, A. (1992). Terminology and ideas regarding the Protogine Zone in southern Sweden. Geologiska Föreningens i Stockholm Förhandlingar, no. 114, p. 360-365. 
Rodrigues, M.L., Machado, C.R. \& Freire, E. (2011). Geotourism routes in urban areas: a preliminary approach to the Lisbon geoheritage survey. GeoJournal of Tourism and Geosites, no. 8, vol. 2, p. 281-294.

Rubinowski, Z. \& Wójcik, Z. (1978). Odsłonięcia geologiczne Kielc i okolic oraz problemy ich ochrony i zagospodarowania [Geological outcrops of Kielce and the surrounding area, as well as problems of their protection and development]. Prace Muzeum Ziemi, no. 20, p. 95-121.

Rudolph, F. (2012). Beach stones. Collecting \& determining stones on the Baltic coast, 11th edn. Wachholtz, Neumünster.

Rudolph, F. (2017). The big book of beach stones. The 300 most common stones on the coast of North and Baltic Sea. Wachholtz Murmann Publishers, Neumünster.

Ruszkowski, M. (2019). Rudy darniowe na ziemi Łowickiej. [Iron ore deposits in the Łowicz Region]. Nowy Kamieniarz, no. 2, vol. 108, p. 76-82.

Scholz, H. \& Obst, K. (2004). Einführung in die Geologie Skandinaviens. Geographische Rundschau, no. 56, vol. 2, p. 43-49.

Schulz, W., (1964). Die Findlinge Mecklenburgs als Naturdenkmäler. Archiv für Naturschutz, no. 4, vol. 3, p. $99-126$.

Skwara, M. (2002). Pruszków. Nasze miasto. [Pruszków. Our town]. Powiatowa i Miejska Biblioteka Publiczna im. H. Sienkiewicza w Pruszkowie, Pruszków.

Smed, P. \& Ehlers, J. (2002). Steine aus dem Norden. Geschiebe als Zeugen der Eiszeit in Norddeutschland. Gebrüder Borntraeger. Berlin, Stuttgart.

Słomka, T. \& Kicińska-Świderska, A. (2004). Geoturystyka - podstawowe pojęcia [Geotourism - basic vacabulary]. Geoturystyka, no. 1, vol. 1, p. 5-7.

Speetzen, E., (1998). Findlinge in Nordrhein-Westfalen und angrenzenden Gebieten. Geologisches Landesamt Nordrhein-Westfalen, Krefeld.

Tomczak, E. (2007). Starożytne centrum metalurgiczne koło Warszawy. Zagadnienia dyskusyjne. [Ancient metallurgical center near Warsaw. Discussion issues]. Archeologia Polski, no. 52, vol. 1-2, p. 177-186.

Wolniewicz, P., (2019). Bringing the History of the Earth to the Public by Using Storytelling and Fossils from Decorative Stones of the City of Poznań, Poland. Geoheritage. https://doi.org/10.1007/s12371-01900400-2 Accessed 25.08.2019 [access 25.08.2019].

Woyda, S. (2002). Mazowieckie centrum metalurgiczne z młodszego okresu przedrzymskiego i okresu wpływów rzymskich [Mazovian metallurgical center from the younger pre-Roman period and the period of Roman influence]. In S. Orzechowski (Ed.), Hutnictwo świętokrzyskie oraz inne centra i ośrodki starożytnej metalurgii żelaza na ziemiach polskich [Świętokrzyskie metallurgy and other centers of ancient iron metallurgy in the Polish lands]. Wydawnictwo Świętokrzyskie Stowarzyszenie Dziedzictwa Przemysłowego, Kielce, p. 151-154.

Woyda, S. (2006). Mazowieckie Centrum Metalurgiczne z czasów Imperium Rzymskiego [Mazovian Metallurgical Center from the time of the Roman Empire]. In I. Horban, Z. Chmurowa \& G. Zegadło (Eds.), Przegląd Pruszkowski, nos. 1-2, p. 5-9.

Xun, Z. \& Tin, Z., (2003). The socio-economic benefits of establishing national geoparks in China. Episodes, no. 26, vol. 4, p. 302-309.

Yuliawati, A.K., Rofaida, R., Gautama, B.P. \& Hadian, M.S.D. (2019). Geoproduct Development as Part of Geotourism at Geopark Belitong. Conference Proceedings, 1st International Conference on Economics, Business, Entrepreneurship, and Finance (ICEBEF 2018) https://doi.org/10.2991/icebef-18.2019.27 [access 15.07.2019].

Zagożdżon, P. \& Śpiewak, A. (2011). Kamień w architekturze a geoturystyka miejska - przykłady z terenu Wrocławia [Stone in architecture and urban geotourism - examples from the area of Wroclaw]. Prace Naukowe Instytutu Górnictwa Politechniki Wrockawskiej 133, Studia i Materiały, no. 40, p. 123-143.

Zagożdżon, P. \& Zagożdżon, K. (2015). Kamienne elementy architektury miejskiej jako geologiczne zaplecze edukacyjne - przykłady wrocławskie [Stony elements of urban architecture as a geological educational background - Wrocław examples]. Przeglad Geologiczny, no. 63, vol. 3, p. 150-154.

Zagożdżon, P. \& Zagożdżon, K. (2016). Wybrane aspekty geoturystyki w Polsce - obiekty podziemne i geoturystyka miejska [Selected aspects of geotourism in Poland - underground facilities and urban geotourism]. Przegląd Geologiczny, no. 64, vol. 9, p. 739-750.

Zandstra, J. G. (1999). Platenatlas van noordelijke kristalijne gidsgesteenten. Backhuys Publishers, Leiden.

Zwoliński, Zb. (2004). Geodiversity. In A. Goudie (Ed.), Encyclopedia of Geomorphology. London: Routledge, p. 417-418.

*** National Geographic (2005). Geotourism Charter http://www.nationalgeographic.com/travel/sustainable/ pdf/geotourism_charter_template.pdf> [access 12.11.2015].

*** Pruszków Stop (2007). A study commissioned by the Commune Pruszków by PBS DGA Company o.o. <http://www.pruszkow.pl/poznaj-miasto/przystanek-pruszkow > [access 10.11.2015].

http://mshm.pl/wp/.

https://www.geocaching.com/play access on 11.06.2019.

http://trino.pttk.pl/ in Polish access on 11.06.2019.

Submitted:

17.07.2019
Revised:

29.10.2019
Accepted and published online 31.10 .2019 